\title{
Consumer Behaviour of Generation $Z$ in the Context of Dual Quality of Daily Consumption Products on EU market
}

\author{
Marianna Šramková1, ${ }^{*}$, and Mária Sirotiaková ${ }^{1}$ \\ ${ }^{1}$ University of Matej Bel, Faculty of Economics, Institute of Managerial Systems in Poprad, \\ Francisciho 910/8, 05801 Poprad, Slovakia
}

\begin{abstract}
.
Research background: The paper focuses on the issue of dual quality of daily consumption products through the lens of the $\mathrm{Z}$ generation. $\mathrm{Z}$ generation is a generation of people born between years of 1997-2012, a generation that will become the main purchasing power in a few years.

Purpose of the article: The purpose of the research was to explore the possibility whether the information on dual product quality affects the consumer behaviour of members of $\mathrm{Z}$ generation and if so, to what extent and at what type of products.

Methods: Main method to receive necessary data for analyse was a questionnaire and its statistical evaluation given hypothesis. The research was carried out in the form of a survey consisted of 227 consumers.

Findings \& Value added: The results show that $85 \%$ of them had dual quality information, perceived this issue as a serious problem, and the majority wants to be informed more about this issue. More than half of the $\mathrm{Z}$ generation had changed their consumer behaviour as a result of information about the dual quality of goods on market of European Union, especially women with higher education and the $\mathrm{Z}$ generation living in rural areas. Research confirmed that the change in behaviour mainly concerns non-food products such as cosmetics and clothing.
\end{abstract}

Keywords: Dual quality; Z Generation; Non-food products; Consumer behaviour

JEL Classification: $Q 18 ; M 38 ; M 31$

\section{Introduction}

Although the issue of double quality is currently combined and addressed mainly in connection with food, the first products that were recorded in Slovakia that can be bought abroad in a different quality were drugstore and cosmetics. Already in the 90 s of the last century [1] some residents of Slovakia noticed that cosmetics (e.g. creams or body lotions),

* Corresponding author: marianna.sramkova@umb.sk 
which they regularly buy and know at home, bought abroad under the same brand in the same or very similar packaging, has a different consistency, the intensity of the scent that will last longer. Similar experiences have been reported with washing powders.

When comparing two products of the same brand, one purchased in Slovakia and the other abroad (especially Germany, Austria, Switzerland), they had at first sight different numbers of "coloured", i.e. active substances. There were many more of them in abroad and, based on experience, it was enough to add less powder to the wash to achieve the same effect as with the Slovak product. Henkel, the manufacturer of the Persil washing powder, has acknowledged the different composition of the brand's products for the EU's western and eastern countries. They defended this with different types of stains and different washing habits in different countries. So this practice was also confirmed and acknowledged by producers in the case of non-food goods [2].

Other cases concerned fabric softeners - those from abroad were denser, smelled more intensely, it was enough to add a smaller amount to the laundry, and yet they smelled the laundry longer after washing.

Another test of washing powders was the test of the Czech magazine dTest, which in 2017 tested washing powders and gels that were visually as similar as possible [3]. According to the test, washing powders purchased in both countries had approximately the same washing effect, but differences in composition were found. German washing powders contained more phosphorus and fewer perfumes - which are potential allergens.

Differences in quality were found even with toilet paper [3]. The compared Czech toilet paper had two layers, the paper in the same packaging bought in Austria was in a threelayer design. The Czech paper received a better evaluation in the testing of strength and absorbency, in the solubility tests and practical tests, in which the softness, pleasantness to the touch and tearing off of the first piece were evaluated, the Austrian version was again better. The test has clearly shown that toilet paper in the same packaging of the same brand purchased in different countries has different composition and properties.

The Czech magazine dTest also tested two types of baby diapers [4], comparing Czech products with products from Hungary and Poland. In both cases, products from Hungary and Poland achieved a different - better - rating than those from the Czech Republic. This is another example of different quality - even non-food - goods being imported into different EU countries. Although in this case we cannot talk about a different quality that would divide the EU to East and West, respectively to the old and new member countries, it is evident that double quality exists.

Another non-food product tested was dog food, which was compared in the Czech Republic and Sweden. Products with identical packaging differed mainly in fat quality, which was affected by different proportions of omega- 6 fatty acids and linoleic acid, in data on minerals and trace elements, and the declaration of crude fibre and ash [4]. All products purchased in Sweden performed better than products from the Czech Republic.

The European Commission itself states that the issue of dual quality includes not only food but also non-food goods, such as cosmetics, toiletries and products intended for infants $[5]$.

The research conducted by the Faculty of Economics of the Matej Bel University in Banská Bystrica, Slovakia in 2019 was also focused on the experience with the double quality of non-food goods. According to the survey, a third of respondents have experience with the dual quality of non-food goods, namely: $23 \%$ have experience with cosmetics, $23 \%$ with detergents, $34 \%$ with laundry detergents and $8 \%$ in clothing. Other non-food goods, with a double quality they have already encountered, mentioned: electronics, computers, shoes and cars. Here, however, we emphasize that such products have not been the subject of any testing and are only the subjective experience of the respondents [6]. In 
our research, we focused on respondents aged 19-25, who represent Generation Z and their view on the issue of double product quality.

Generation Z (Post-Millennials) is a demographic cohort that follows Generation Y (Millennials). It applies to people born between 1997-2012, with slight variations [7]. Other names have been adopted for this generation group, such as: iGeneration, Gen Tech, Gen Wii, Net Gen, Digital Natives, and Plurals [8]. Significant for this generation is the considerable extent of the use of Internet technologies.

They start with them from a very young age. Members of Generation $\mathrm{Z}$ are identified with technology and interact with social Internet networks, which represent a significant part of their social life. Nedelko and Cresnar claim that they already have technology in their DNA [9]. It is the most technically advanced generation of all time [10]. While the socalled millennia grew up on television and the internet came as another medium, for Generation $\mathrm{Z}$ the internet has been a number one and the social media ubiquitous [11].

What is Generation Z? Like the generations before them, they have their positives and negatives. They are technologically advanced, they can absorb a lot of information and also search for it quickly. The daily life of Generation $\mathrm{Z}$ is an open book and they do not know what discretion is. They share their joys and achievements, worries and pains, they present positive and negative experiences to their "audience" through social networks and blogs [12]. They also watch television programs mostly through mobile devices [13]. They are "surgically" attached to a cell phone. They can easily build relationships and they have a strong social network that is not limited by geography.

They make decisions in a group, a team, they like to communicate and find out the opinions of others. It is typical for them to do many things at once, they do not tolerate boredom and few stimuli. They are considered highly educated, creative and innovative, able to perform tasks in an ever-changing environment [14]. They have a high moral code, their worldview is strongly influenced by the nature of human rights and antidiscrimination laws. They need to live in conditions where these values are incorporated.

They are independent thinkers, accustomed to acting, looking for opportunities and seizing them, looking for experiences that move their lives always forward towards higher ambitions, have an entrepreneurial spirit and are creative. They are able to overcome themselves [15]. Because they are used to e-mail communication or telephoning, face-toface meetings are not their strong point [16]. Also their basic skills and grammar will make their lives more and more difficult.

The current members of Generation $\mathrm{Z}$ fall into the developmental period of adolescence and early adulthood, which is characterized by an effort to differentiate themselves from their surroundings (e.g. in clothing, music) and the creation of a specific lifestyle, the socalled youth culture. It is a period of searching for one's own identity, uniqueness and authenticity, a period of social moratorium, i.e. time to search and experiment in different areas. They are characterized by the need for urgent satisfaction, which usually manifests itself in a tendency to shorten the time necessary to achieve a goal, they consider delay to be a burden. It is important for them what they wear, they choose fashion brands that are just "in", they buy quality cosmetics. They are among the smart online consumers who can find the best offer [17]. They are mass-influenced by various corporations, they need to be successful and they want to have quality things. They don't believe what companies try to tell them, what retail chains offer them. They only believe in two things. To what they create, resp. they try it for themselves and what friends and acquaintances tell them. Generation $\mathrm{Z}$ consumers are interesting and seem like a challenge to traders because they want to express themselves, often through shopping behaviour and buying. Similarly, Generation $\mathrm{Z}$ customers often encounter brands that support their self-perception or desired self [18]. They are more than brand saturated. They are focused on the world, visually engaged. They have no problem comparing the quality and price of individual products or 
services very quickly. Important information for them is the one which is on social networks [19]. They also travel a lot and like to travel, so they have no problem comparing the quality of different goods offered at home and abroad. This generation is much more likely to invest in experiences than in mortgages or buying a new car. It's a generation that has already been born with knowledge of technology - they are used to finding the whole world in their mobile, they are active, they are looking for information and they are demanding quality. They already have great purchasing power and it will grow. They are a confident generation unencumbered by a period of real socialism, a generation that has no inhibitions. They are fully in line with their peers from Western Europe, recognizing the same values and interests. The online world is their natural communication world, with which they fully integrate, often at the expense of direct personal communication. It is a generation affected by the amount of available information, new technologies which they have off pat their fingertips and with good language skills, which creates a demanding consumer in a period of real consumerism.

These theoretical starting points were the basis for our main goal and subsequent subgoals.

\section{Methods}

The main objective was to determine whether information and experience with the dual quality of daily consumer goods in the EU influence the consumption behaviour of Generation $\mathrm{Z}$ customers and to formulate recommendations based on the results. This goal was followed by sub-objectives: to find out whether Z-generation customers have information on the issue of dual quality, to find out how they perceive this issue, what attitude they took to it, to find out whether the behaviour of Z-generation customers changed under the influence of information, resp. from experience with dual quality goods, and then find out what type of assortment changed consumer behaviour of Generation $\mathrm{Z}$ when they do the shopping.

Based on theoretical knowledge and in accordance with the formulated goals, we set the following hypotheses:

$\mathrm{H} 1$ : We assume that more than $80 \%$ of customers of the generation $\mathrm{Z}$ is aware the issue of dual quality of goods.

$\mathrm{H} 2$ : We assume that more than $50 \%$ of customers of the generation $\mathrm{Z}$ changed their buyer's behaviour on the basis of information or experience with dual quality goods.

$\mathrm{H} 3$ : We assume that customers of the generation $\mathrm{Z}$ influenced by the existence of dual quality tend to change their buyer's behaviour more when purchasing the non-food products rather than food products.

Various statistical methods were used to evaluate data and discover relevant information. For hypotheses verification and to provide more detailed image of the situation in Slovak manufacturing industry statistical tests such as Binomial test, Factor analysis and Pearson correlation test were used. Furthermore, Chi-square test was used to verify the representativeness of the sample file.

We conducted the research on a sample of 919 respondents, but for the purposes of this paper we will be interested in a group of respondents aged 19 to 25 years, which in our research consisted of 227 respondents - see Table 1.

The main method of data collection was a questionnaire, which we supplemented with structured interviews with a third of respondents within focus groups. 
Table 1. Research sample structure

\begin{tabular}{|c|c|c|c|c|c|c|c|c|}
\hline \multirow{2}{*}{$\begin{array}{l}\text { Structure of } \\
\text { the research } \\
\text { sample } \\
\text { (in \%) }\end{array}$} & \multicolumn{3}{|c|}{$\begin{array}{l}\text { Monthly income of } \\
\text { household (in euro) }\end{array}$} & \multicolumn{3}{|c|}{ Education } & \multicolumn{2}{|c|}{ Living location } \\
\hline & $\begin{array}{c}0- \\
1000\end{array}$ & $\begin{array}{c}1001- \\
1600\end{array}$ & $\begin{array}{l}\text { over } \\
1006 \\
\end{array}$ & Primary & Secondary & Tertiary & Village & City \\
\hline Female & 32 & 42 & 26 & 0 & 38 & 62 & 52 & 48 \\
\hline Male & 35 & 26 & 39 & 3 & 55 & 42 & 49 & 51 \\
\hline
\end{tabular}

\section{Results and discussions}

According to the results, 195 respondents, representing $86 \%$ of respondents, sometimes heard about the problem of dual quality of goods of the same brand in individual EU countries. For $85 \%$ of them, dual quality is an important problem, with $96 \%$ hearing about this problem from the media, 59\% having personal experience and $49 \%$ knowing a person with personal experience with products of different quality. Less than a third of the $Z$ generation has personal experience, or an acquaintance with personal experience with the dual quality of non-food goods.

Hypothesis H1 was tested by Binomial test, where calculated $\mathrm{p}$ value from research was 0,74 and was compared with $p$ value of test. We can accept hypothesis if tested value is more than 0,5 . It was discovered that $85.91 \%$ of customers of generation $\mathrm{Z}$ is aware of the issue of dual quality and the results of the test also proven our initial assumption of the awareness rate. Based on the test results, we can state that the H1 hypothesis that more than $80 \%$ of Z-generation respondents in our research heard about the issue of dual food quality was confirmed. There has been a lot of talk about the issue recently, especially through the media, which has also been confirmed by our respondents. The media is an important opinion-forming factor co-creating the lives of individuals, groups and society as a whole, and it is not possible to isolate oneself from their influence. Their aim is to consciously change how consumers think about and approach a particular product [20]. The power of the information shifted by the media is so great that we are sometimes able to believe it faster than to believe our own eyes. Our respondents - generation $\mathrm{Z}$ - are already growing together with digital technologies and at the time of the development of social networks. These people can be online 24 hours a day, 7 days a week. What has most affected this generation is technological progress. Generation $\mathrm{Z}$ already works with information differently than the generation before them. They work with them throughout the day and do not wait for an hour to watch the news on TV. Generation $\mathrm{Z}$ is specific in that it changes television to other screens (especially a smartphone, tablet) and has fun almost exclusively online. They draw information from multiple sources, not only from one radio, television or website. Generation $\mathrm{Z}$ lives with a constant inflow of information.

How do members of Generation $\mathrm{Z}$ perceive the issue of dual product quality in the EU? As many as $76 \%$ of respondents aged 19 to 25 said that the problem of dual quality hindered them. Most consider dual quality to be an ethical as well as a legislative issue. Young people have a developed sense of justice, which dominates obedience and respect in this period of development. They are critical of unfairness, deception and misleading. Violations of standards by others are perceived as a loss of validity. They are at a stage of morality oriented towards universal ethical principles. They accept a system of laws as long as it does not conflict with their personal experience. But they no longer accept individual rules passively, but want to decide for themselves on the basis of their own moral principles. They accept responsibility for themselves, they internalize the concept of justice and freedom [21], which was confirmed in our research. 
Almost $88 \%$ of Generation $\mathrm{Z}$ are interested in being informed about cases of dual quality goods. In the first place concerning the ways of information they prefer are the media, and in the second place it is a transnational website informing about the identified problems. Such a site was originally supposed to be created under the auspices of the Slovak Republic in the fall of 2017, but has not been launched to this day. At the same time, $85 \%$ of respondents are willing to inform about their experience with dual quality products. They chose a specialized website, social networks (a specialized profile where it would be possible to upload photos and information directly) and a mobile application designed for this purpose as opportunities to share their experience. Based on these facts and findings, and of course with respect to the results of Binomial test, we confirmed the hypothesis $\mathrm{H} 1$.

Hypothesis $\mathrm{H} 2$ was also tested by Binomial test, where calculated $\mathrm{p}$ value from research was 0,62 and was compared with $p$ value of test. We can accept hypothesis if tested value is more than 0,5 . Result shows, that hypothesis H2, which assumed that more than half of Zgeneration respondents changed their consumption behaviour as a result of information on cases of double quality goods, was confirmed. Specifically, up to $71 \%$ of respondents changed their shopping behaviour. There are consumers who, before buying daily consumer products, are looking for and appreciating the widest possible range of information that points to the quality of the products they buy. And only after studying they will decide to buy. More than half of our respondents belong to this group of consumers. Here are some of their statements that we obtained through individual inquiries within focus groups: „Ever since I heard about double quality, I've been studying more about the proportion of meat in products." „Since I travel abroad, I notice the quality of the products, I take care of it. „I don't buy cheap goods anymore.” "If I have a choice, of course I will prefer a higher quality product and I am also more interested in it.” "Recently, I have been more attentive to what I buy. I'm already studying labels more and looking for information about the products."

Others, those who already have an established attitude to a product, decide on their next purchase according to their beliefs and choose the product with which they have been satisfied in the past and do not place much emphasis on all the information that may indicate that some manufacturers they supply their products to different countries under the same brand but in different quality. Some of our respondents also agreed with this: „I rely on what I like, not on product information." „I like our Nutella, I want it and I don't care what the quality is." „I'm hungry, I want to meet my needs now, so I buy it and I don't solve anything else." „I don't mind, it offends me that the producers do it, but I still consume what I like, whether it's healthy or no." „It's my habit to buy the bars, I like them and I don't care what the quality is, I don't solve it." Here it was confirmed that Generation Z needs to meet their needs now and here and that many of them rely on their judgment and experience.

It is also possible for these consumers to change their consumer behaviour, but it will not be automatic. In this case the following is important when changing attitudes or behaviours: the source of communication (e.g. degree of expertise or attractiveness), the communication itself (e.g. quality of arguments or whether the communicator presents both sides of the problem) and the nature of the consumer (whether the customer's attitude towards the point of view is hostile or friendly). A possible explanation for why some respondents have not changed their shopping behaviour is this: "I live with my parents in the same household and I am not the one who buys and manages money." Here is the question of whether the $\mathrm{Z}$ generation will change its shopping behaviour and what products will be concerned if they are independent and move away from their parents and manage their own financial resources.

When will people be affected by what the media, resp. other social sources express, report? What is important is the extent to which the issue is personally important to them. 
The more relevant a particular issue is the more people are willing to pay attention to the arguments provided by the various sources.

The data in Table 2 offer us a few more interesting things.

Table 2. The rate of change in buyers' behaviour

\begin{tabular}{|c|c|c|c|c|c|c|c|c|}
\hline \multirow{2}{*}{$\begin{array}{c}\text { Rate of change in } \\
\text { buyers' behavior (in } \\
\text { \% of customers) }\end{array}$} & \multicolumn{3}{|c|}{$\begin{array}{c}\text { Monthly income of } \\
\text { household (in euro) }\end{array}$} & \multicolumn{4}{c|}{ Education } & \multicolumn{2}{c|}{$\begin{array}{c}\text { Living } \\
\text { location }\end{array}$} \\
\cline { 2 - 9 } & $\begin{array}{c}\mathbf{0}- \\
\mathbf{1 0 0 0}\end{array}$ & $\begin{array}{c}\mathbf{1 0 0 1} \\
\mathbf{1 6 0 0}\end{array}$ & $\begin{array}{c}\text { over } \\
\mathbf{1 6 0 1}\end{array}$ & Primary & Secondary & Tertiary & Village & City \\
\hline Female & 74.42 & 78.69 & 73.08 & - & 66.67 & 81.25 & 79.17 & 70.00 \\
\hline Male & 65.00 & 46.67 & 66.67 & 50.00 & 57.89 & 65.52 & 64.10 & 59.38 \\
\hline
\end{tabular}

As we can see, Z-generation women are more likely to change their shopping behaviour than men. And they are women, especially with a university degree. On the other hand, men with basic education change their habits the least. These men form a subculture that prefers an unpretentious and stereotypical way of life that does not change. The basis is the satisfaction of basic needs (they buy the same food, in the same shops) and entertainment needs (watching football matches, visiting hospitality facilities, ...). The results in our table show that the more educated a person is, the more he thinks about the issue and then, after considering the pros and cons, he changes his shopping behaviour.

Another finding is the difference in the change in consumer behaviour regarding dual quality with respect to the type of settlement of respondents. More people (regardless of gender) living in the countryside are changing their shopping behaviour - than people living in cities. We are offered such an explanation. Our respondents and their parents live in the countryside of eastern Slovakia, where there is high unemployment. Almost at least one member of the household is forced to travel abroad for work. And of course he will try and compare the quality of products of the same brand. He will gain his own experience, an experience that he shares with others when he returns home, and it is a great assumption that they will also begin to pay more attention to the quality and composition of the products. Of course, this is just one of the possible interpretations. Based on these facts and findings, and of course with respect to the results of Binomial test, we confirmed the hypothesis $\mathrm{H} 2$.

This assumption was further explored by examining the hypothesis H3, which we tested using the Pearson correlation test. The two factors which were correlated were the awareness of dual quality and potential change in buyer's behaviour. Factor analysis was used the structure the data since the research covered many various products. This related to the assumption that customers of the generation $\mathrm{Z}$ focus more on the dual quality of nonfood related products. However, the test results were inconclusive. The relationship between the awareness of dual quality and potential change in buyer's behaviour was not proven to be significant enough to confirm the hypothesis $\mathrm{H} 3$ since the correlation coefficient was calculated at the level 0.022 , which indicates that there is no dependence between these factors. Therefore, it is possible to conclude that awareness of dual quality influences the changes in buyers' behaviour, however there are no significant differences between non-food and food products. According to the research results, customers of the generation $\mathrm{Z}$ who changed their buyer's behaviour changed it almost equally for non-food $(51 \%)$ and for food products $(49 \%)$. The differences were mainly in clothing, footwear and cosmetics since these products are very important to them in terms of how their care for how they look and how they like to fit in with their peers. 
Although hypothesis 3 was not confirmed, the following statements of the respondents of the Generation $\mathrm{Z}$ regarding non-food products are important for us and perhaps also for producers: "I want to be trendy and it is important for me to have quality and branded shoes, those bought in our country are fakes, I will buy the same, better quality and even cheaper over the internet from abroad." „I go to Vienna with a friend and there I buy the same cream, shampoo, conditioner for a better price and much higher quality." „I would be ashamed to leave house, if I did not have quality branded clothing, my father brings it from Switzerland, ours cannot be worn." „The quality and price of washing powder and fabric softener of the same brand purchased in Slovakia and Austria or Germany cannot be compared. I don't even buy washing powders here in Slovakia." „If my classmate has quality and branded clothes, I won't be worse. " „I can't jut out from the crowd, I have to be random, so I watch on the internet where to buy better clothes."

On the other hand, this is how respondents commented on the issue of dual quality food products: „I can't keep up with composition labels for food, because I'm in a hurry in the store, there are a lot of goods and they are cluttered, so I don't waste time and take the first thing I see." „I don't care so much about food as it is, because no one sees what I consume."

These statements also show that the "cult of the body" is what matters to the $\mathrm{Z}$ generation, what they look like than how they eat. The look has become a goal and a means [22]. The dictates of fashion, advertising and especially the media (they are online on the Internet) lead them to constantly improve their bodies, their appearance, to go hand in hand with current trends. External look can be influenced more easily and quickly, than psychic qualities, or the behaviour itself. It is inadmissible for them, and even as it is embarrassing or humiliating to wear unbranded clothing or to use low-quality secondary cosmetics, they represent their status through branded products. They need to please themselves and others to be sure of their value. Today, they are the ones who decide who they want to be or what they want to be. They consider the free presentation of their unique personality, even by means of cult of beauty, not only as their right, but also as a symbol of status.

We managed to meet the set goals. Respondents from the $\mathrm{Z}$ generation have information on the issue of dual product quality. They obtained them mainly from the media and through their own experience. They are not indifferent to the topic, they perceive it as an ethical and at the same time legislative problem. They want to keep them informed. Based on the information obtained on dual quality, they change their consumer behaviour, mainly with regard to non-food products.

\section{Conclusion}

Each generation has always been specific and its life reflected the time in which the generation was born [23], [24]. Today's generation of young people is also trying to survive in the world they are in. Generation $\mathrm{Z}$ is the generation for which there is, resp. there will be a market battle. In many segments, whether products or services, they are key customers. Although this is a generation that does not have great purchasing power yet, it is very interesting and important from a perspective point of view, because it is only a matter of a short time before they become mainstream determining consumer behaviour. At present, they are not very interested in buying food and ordinary household goods, as parents buy it for them, but rather focus on making decisions when buying goods that are important to them in terms of their appearance and position in social groups. This is where their greater interest in purchasing is reflected. With such goods, they perceive the issue of dual quality of goods in Europe, find out information and prefer to buy quality goods abroad (which is not a problem at all with today's possibilities of online shopping and fast international distribution, and young people know how to use it), as they should prefer the graceful version at home. They consider the behaviour of multinational brands, which place goods 
of different composition and quality on the markets of different countries, to be unfair. However, they do not know how to defend themselves and therefore, according to them, this issue should be addressed by national institutions such as trade inspections that have better ways to punish these practices of brand manufacturers.

In the near future, however, Generation $Z$ people will start making all their purchases and will be increasingly demanding on the quality of both non-food and food goods, especially when they start their own households and families. Manufacturers of multinational brands should thus build a good reputation and good relationships with the $\mathrm{Z}$ generation in order to retain this group of potential customers in the future. They should be positioned as quality, fair and honest producers, because young people are very aware of the issue and know how to get information about it quickly.

Generation $\mathrm{Z}$ grows up in a culturally diversified society and it is a highly culturally tolerant group. They travel a lot, get to know other cultures and have no problem accepting foreign cultural elements. It is natural for them that different nationalities have different tastes and preferences, and it is normal for them that the products of multinational manufacturers also adapt to these nationalities. But the fact that these products with different compositions are packed in the same package without the customer realizing it at first sight is not considered correct. More than $78 \%$ of our respondents consider it an acceptable solution to package products with different compositions into different packages and to value them at the appropriate price. We therefore suggest to manufacturers that they make the argued diversity of local tastes and preferences an advantage and present it to consumers through different packaging.

This contribution was supported by the project No. 1/0757/18, "Consumer behaviour in buying goods of daily consumption with an emphasis placed different contents of goods offered on markets of selected EU countries".

\section{References}

1. Čimová, D. (2017, March 3). Na Slovensku sme výrobkom ponechali názvy, ale charakter sme im zmenili. DennikN. https://e.dennikn.sk/707216/na-slovensku-smevyrobkom-ponechali-nazvy-ale-charakter-sme-im-zmenili/

2. European Commission. (2018, September 10). Summary of studies on quality differentiation of products. AsktheEU. https://www.asktheeu.org/fr/request/4975/response/16130/attach/18/Annex\%20II\%20item\%2034\%20Ares\%202018\%20730274 .pdf

3. Bartková, L., Veselovská, L. (2020). The Impact of the Media on the Perception of Dual Quality Goods in the European Union. The Scientific Papers of the University of Pardubice, 28(2), 1064.

4. Dtest. (2018, November 14). Dětské jednorázové pleny Pampers. dTest. https://www.dtest.cz/clanek-7054/detske-jednorazove-pleny-pampers-dtest-11-2018

5. European Parliament. (2018, July 19). Report on dual quality of products in the single market. European Parliament. http://www.europarl.europa.eu/doceo/document/A-82018-0267_EN.html

6. Bartková, L. (2019). How do consumers perceive the dual quality of goods and its economic aspects in the European Union? An empirical study. The Problems and Perspectives in Management, 17(3), 382-394.

7. Mahmoud, Ali B., Fuxman, L., Mohr, I., Reisel, W., Grigoriou , N. (2020).’We aren't your reincarnation!“ workplace motivation across $\mathrm{X}, \mathrm{Y}$ and $\mathrm{Z}$ generations. The International Journal of Man-power, 41(6), 28-44. 
8. Horovitz, B. (2012, May 4). After Gen X, Millennials, what should next generation be? Usatoday. http://usatoday30.usatoday.com/money/advertising/story/2012-0503/naming-the-next-generation/54737518/1

9. Nedelko, Z., Creasnar, R. (2020). Understanding future leaders: How are personal values of Generations $\mathrm{Y}$ and $\mathrm{Z}$ tailored to leadership in industry 4.0? Sustainability, 12(11), 4417.

10. Kai-Yu, W., Wen-Hai, Ch., Li-Chun, H. et al. (2020). Investigating apology, perceived firm remorse and consumers' coping behaviour in the digital media service recovery context. The Journal of Service Management, 31(1), 57-76.

11. Veselovská, L., Kožárová, M., Závadský, J. (2018). Relationship between information sharing and flexibility in management of enterprises in automotive industry: an empirical study. The Serbian Journal of Management, 13(2), 381-393.

12. Khernová, V., Kostolanská, J. (2017). Generácia Z v kontexte národných meraní zo slovenského jazyka a literatúry. Edukácia, 2(1), 109-116.

13. Rodney, D. (2020). The youTube marketing communication effect on cognitive, affective and behavioural attitudes among Generation $Z$ consumers. Sustainability, 12(12), 5075.

14. Mueke, R. V., Schänzel, H. A. (2019). A tourism inflex: Generation Z travel experiences. The Journal of Tourism Futures, 5(2), 127-141.

15. Combi, CH. (2015). Generation Z: their voices, their lives. London: Hutchinson.

16. Ismail, A. R., Nguyen, B., Chen, J., Melewar, T. C., Bahtiar, M. (2020). Brand engagement in self-concept (BESC), value consciousness and brand loyalty: a study of Generation Z consumers in Malaysia. The Young Consumers, 20(1), 123-137.

17. Tseng, CH., Wei, L. (2020). The efficiency of mobile media richness across different stages of online consumer behaviour. The International Journal of Information Management, 50(1), 353-364.

18. Taylor, R. L. C. (2020). A mixed bag: The hidden time costs of regulating consumer behavior. The Journal of the Association of Environmental and Resource Economists, 7(2), 345-378.

19. Sebald, A., Vikander, N. (2019). Optimal firm behaviour with consumer social image concerns and asymmetric information. The Journal of Economic Behaviour \& Organization, 167(4), 311-330.

20. Veselovská, L. (2020). Supply chain disruptions in the context of early stages of the global COVID-19 outbreak. The Problems and Perspectives in Management, 18(2), 490-500.

21. Vágnerová, M. (2012). Vývojová psychologie II. Dospělost a stáří. Praha: Karolinum.

22. Č́áp, J., Mareš, J. (2017). Psychologie pro učitele. Praha: Portál.

23. Veselovská, L. (2017). Factors influencing countries on their path to sustainable development: implications for organizations. The Problems and Perspectives in Management, 15(2), 475-486.

24. Veselovská, L., Závadský, J., Závadská, Z. (2020). Mitigating bribery risks to strengthen the corporate social responsibility in accordance with the ISO 37001. The Corporate Social Responsibility and Environmental Management, 27(4), 1972-1988. 